\title{
Analisis Dan Perancangan Sistem Informasi Pengelolaan Arsip Perkara Dengan Berorientasi Objek
}

\author{
$\underline{\text { Elvi Yanti }}$ \\ Sistem Informasi, Fakultas Ilmu Komputer, Universitas Dinamika Bangsa \\ Jl. Jendral Sudirman, Thehok - Jambi, Indonesia \\ Elvote92@gmail.com
}

\begin{abstract}
Jambi religious court is required to always provide innovations that are able to improve the quality of public services, one of the public service activities contained in jambi religious courts is to provide legal products in the form of case verdicts where almost every time requested by the litigants. But nowadays it is always constrained by archival searches that take a relatively long time because of labor limitations. Archival management is still done by manual that is noted in the agenda book and stores it in the archive box, this makes the storage space take up space, on the other hand the process of searching archives takes a relatively long time, the risk of archive damage due to disasters, and in this case is considered ineffective and inefficient. To solve this problem, it is necessary to adopt an objectbased approach in analyzing and designing case file management information systems with the aim of minimizing the use of the room used as an archive storage area and can also facilitate and speed up the search of archives when needed so that it no longer makes the public wait too long just to get legal products. In the design process using the OOAD method with UML modeling, and using traceability matrix methods and prototype testing to evaluate the results of system design. The results of the requirements analysis consist of 14 features, 14 functional requirements, 3 non-functional requirements, and 4 actors consisting of 6 use cases. At the evaluation stage uses the matrix traceability method and the result is that all requirements have been determined. The results of the evaluation use a prototype test where all scene processes have met the user's expectations.
\end{abstract}

Keywords : archives, jambi religious court, prototype, traceability matrix

\begin{abstract}
Abstrak
Pengadilan agama jambi dituntut untuk selalu memberikan inovasi yang mampu meningkatkan kualitas layanan publik, salah satu aktivitas layanan publik yang terdapat dipengadilan agama jambi adalah memberikan produk hukum yang berupa hasil putusan perkara dimana hampir setiap saat diminta oleh masyarakat yang berperkara. Namun saat ini selalu terkendala dengan pencarian arsip yang memakan waktu relatif lama karena keterbatasan tenaga kerja. Pengelolaan arsip masih dilakukan dengan manual yaitu mencatat dalam buku agenda dan menyimpannya didalam kotak arsip, hal ini membuat ruang penyimpanan memakan tempat, di sisi lain proses pencarian arsip memakan waktu yang relatif lama, resiko kerusakan arsip yang tinggi akibat bencana, dan dalam hal ini dianggap tidak efektif dan tidak efisien. Untuk mengatasi masalah ini, perlu mengadopsi pendekatan berbasis objek dalam menganalisis dan merancang sistem informasi manajemen arsip perkara dengan tujuan untuk meminimalkan penggunaan ruangan yang digunakan sebagai tempat penyimpanan arsip dan juga dapat memudahkan serta mempercepat pencarian arsip ketika dibutuhkan sehingga tidak lagi membuat masyarakat menunggu terlalu lama hanya untuk mendapatkan produk hukum. Pada proses perancangan menggunakan metode OOAD dengan pemodelan UML, dan menggunakan metode traceability matrix dan pengujian prototype untuk mengevaluasi hasil perancangan sistem. Hasil dari analisis persyaratan terdiri dari 14 fitur, 14 persyaratan fungsional, 3 persyaratan non fungsional, dan 4 aktor terdiri dari 6 use case. Pada tahap evaluasi menggunakan metode traceability matriks dan hasilnya adalah semua persyaratan telah ditentukan. Hasil dari evaluasi menggunakan uji prototipe dimana semua proses adegan telah memenuhi harapan pengguna.
\end{abstract}

Kata kunci : arsip, pengadilan agama jambi, prototype, traceability matrix

\section{Pendahuluan}

Teknologi komputer berperan dalam kinerja setiap organisasi dan komunitas, dengan harapan dapat membantu menemukan informasi yang di butuhkan. Keberadaan arsip bukan hanya sebagai bukti sejarah bagi suatu organisasi, tetapi memiliki fungsi ganda dan nilai guna. Ketika beban kerja meningkat, organisasi akan menghasilkan peningkatan jumlah arsip. Dilihat dari jumlah arsip yang semakin banyak dari waktu ke waktu, maka perlu penanganan yang baik agar dapat dengan cepat dan akurat menemukan informasi yang terdapat dalam arsip tersebut [1]. Arsip adalah sekumpulan data berupa informasi yang diterima dan diperoleh dari suatu organisasi atau individu, dan dimaksudkan untuk disimpan sebagai bukti pelaksanaan kegiatan [2]. Dalam melaksanakan serangkaian aktivitas yang dijalankan oleh 
Pengadilan Agama Jambi dituangkan dalam bentuk notasi yang dirangkai menjadi proses bisnis. Aktivitas-aktivitas yang tertuang dalam proses bisnis ditujukan untuk mencapai tujuan suatu bisnis. Setiap proses bisnis ditetapkan oleh satu organisasi, namun dapat berinteraksi dengan proses yang dijalankan organisasi lainnya [3].

Penelitian [4] menghasilkan aplikasi e-arsip yang berfungsi scan yang kegunaan menginputkan scan surat yang ingin disimpan sehingga dapat menimalkan kehilangan dan rusaknya dokumen-dokumen penting dengan menggunakan pemodelan data Unified Modeling Language (UML). Penelitian [5] menghasilkan aplikasi sistem informasi pengarsipan berkas perkara pidana dan perdata dengan metode pengembangan sistem menggunakan konsep System Development Life Cycle (SDLC) maka pengarsipan menjadi lebih mudah dan cepat, proses pencarian data cepat, dokumentasi rapih dan dalam hal pembuatan laporan pun akan lebih mudah sehingga sangat membantu meringankan pekerjaan petugas arsip. Penelitian [6] menghasilkan aplikasi e-arsip dengan menggukan model sistem waterfall sehingga dalam proses pencarian data dan informasi arsip pada Kanwil Kementerian Agama Provinsi Bengkulu menjadi lebih mudah dan Informasi yang dihasilkan cukup akurat dan cukup valid, dan dapat membantu proses penyelenggara kearsipan yang sesuai dengan prinsip, kaedah dan standar kearsipan. Penelitian [7] menghasilkan pengarsipan administrasi mahasiswa secara digital pada STMIK PalComTech Palembang dengan menggunakan sistem OCR (Optical Character Recognition) dengan metode pencarian string (String Matching) dimana sebagai tool dalam analisis dan desain mempergunakan PHP sebagai bahasa pemrogramannya dan MySQL sebagai basis datanya.

Saat ini Pengadilan Agama Jambi menerima dan memutus perkara setidaknya didalam satu tahun itu mencapai 1500 perkara dimana perkara tersebut menjadi arsip yang akan menumpuk sampai tiba masa pemusnahan arsip (retensi). Pengarsipan yang berjalan di Pengadilan Agama Jambi dilakukan dengan mencatat dalam buku agenda kemudian menyimpan arsip dalam bentuk hard copy dan disimpan dalam kotak arsip yang disusun berdasarkan nomor perkara, jenis perkara, dan tahun perkara. Pengelolaan arsip secara manual yang telah dilakukan selama ini, mempunyai beberapa kelemahan, antara lain: membutuhkan ruang dan tempat penyimpanan yang besar, resiko kerusakan arsip yang tinggi akibat bencana, membutuhkan pegawai yang banyak, dan waktu pencarian yang relatif lama.

Untuk menyelesaikan permasalahan yang ada maka dilakukan dengan menerapkan konsep Analisis dan desain berorientasi objek dengan mengakomodasi objek dan entitas yang digunakan dalam proses analisa sistem [8]. Solusi dari permasalahan tersebut adalah dengan merancang Sistem Informasi Pengelolaan Arsip Perkara, dengan tujuan membantu petugas arsip didalam mengelola arsip perkara yang diperoleh Pengadilan Agama Jambi.

\section{Metodologi}

Penelitian ini penulis lakukan berdasarkan alur penelitian berikut ini.

1. Studi literatur

Penelitian dimulai melakukan langkah studi literatur dengan mempelajari, mencari dan menyusun dasar teori dan referensi dari penelitian yang akan dilakukan. Sumber referensi dalam melakukan studi literatur dapat diambil melalui buku, hasil konfrensi, dan laporan penelitian sebelumnya yang sejenis.

2. Pengumpulan data

Pengumpulan data dilakukan dengan cara wawancara. Hal ini bertujuan untuk mengetahui permasalahan dan mendefinisikan kebutuhan sistem yang sesuai dengan yang diinginkan oleh Kepaniteraan Pengadilan Agama Jambi dalam menyelesaikan permasalahan yang ada pada Pengelolaan Arsip Perkara saat ini. Narasumber dalam proses wawancara ini adalah Panitera Muda Hukum Pengadilan Agama Jambi. Informasi yang digali pada proses wawancara berkaitan tentang bagaimana untuk mendapatkan kebutuhan dari sistem sehingga penelitian yang dilakukan dapat memberikan solusi yang sesuai dengan permasalahan yang ada.

3. Pemodelan Proses Bisnis dan Analisis Persyaratan

Pada tahapan ini, langkah pertama yang dilakukan yaitu melakukan pemodelan proses bisnis yang didapatkan pada saat pengumpulan data yang berupa alur pengarsipan perkara pada kepaniteraan pengadilan agama jambi yang hasilnya akan divisualisasikan dalam Business Process Modelling Notation (BPMN). 
4. Perancangan Sistem

Pada tahap perancangan sistem, dilakukan beberapa pemodelan dengan menggunakan notasi Unifying Modeling Language (UML) yang bersumber dari pemodelan use case yang telah terdefinisi pada tahap sebelumnya. Pemodelan yang dilakukan pada perancangan sistem ini adalah pemodelan objek yang menghasilkan class diagram, pemodelan interaksi antar objek menghasilkan sequence diagram serta menghasilkan Activity Diagram Pada tahap perancangan sistem juga dilakukan perancangan antarmuka yang akan diterapkan pada sistem.

5. Evaluasi Perancangan Sistem

Bagian ini penelitian melakukan evaluasi dari perancangan sistem yang telah dilakukan pada tahap sebelum-sebelumnya. Evaluasi pada penelitian ini dilakukan dengan Traceability Matrix dan Pengujian Prototype. Evaluasi dengan Traceability Matrix bertujuan untuk menelusuri perancangan sistem apakah telah memuat semua analisis persyaratan yang telah terdefinisi pada tahap sebelumnya, sedangkan evaluasi dengan Pengujian Prototype bertujuan untuk mengetahui bahwa alur dari semua scenario sudah sesuai dengan yang diharapkan pengguna.

\section{Hasil dan Pembahasan}

\subsection{Proses Bisnis Yang Sedang Berjalan}

Panitera muda hukum menerima berkas perkara yang diserahkan oleh masing-masing Panitera Pengganti kemudian Panitera muda hukum meyerahkan berkas tersebut kepada Petugas arsip dan Petugas arsip mencatat berkas tersebut kedalam buku kontrol penerimaan arsip serta mengecek kelengkapan dan menyusun berkas tersebut berdasarkan jenis perkaranya kemudian memasukkan kedalam box yang telah diberi nomor box dan selanjutkan Petugas arsip membuat daftar isi box tersebut dan menyusunnya kedalam ruang arsip dan kemudian di akhir bulan Petugas arsip membuat laporan penerimaan arsip dan menyerahkan kepada Panitera muda hukum untuk di paraf dan kemudian Panitera muda hukum menyerahkan laporan tersebut kepada Panitera untuk ditanda tangani kemudian Panitera meneruskan Laporan Tersebut kepada Ketua Pengadilan Agama Jambi.

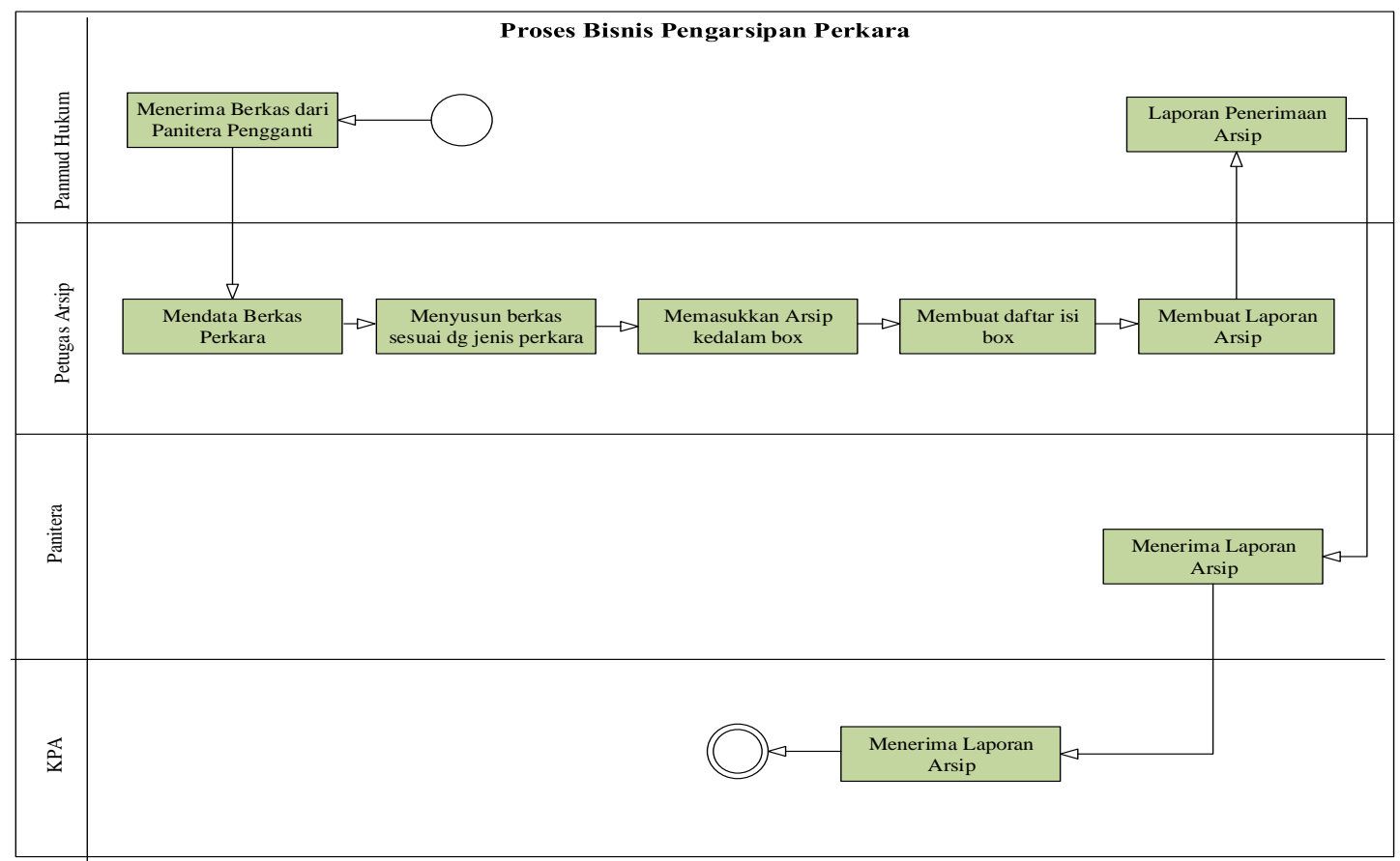

Gambar 1. Proses Bisnis Yang Sedang Berjalan

Dari proses bisnis saat ini dilakukan analisis masalah yang terjadi pada alur proses bisnis pengelolaan arsip perkara saat ini. Indentifikasi pernyataan masalah ini dilakukan sebagai upaya untuk menjelaskan masalah dan membuat penjelesan terkait dengan permasalahan yang ada. Informasi permasalahan yang didapatkan didefinisikan dalam daftar pernyataan masalah yang ditunjukkan pada tabel 1 berikut ini. 
Tabel 1. Pernyataan masalah

\begin{tabular}{ll}
\hline Masalah & 1. Sulitnya dalam penemuan kembali arsip ketika dibutuhkan karena penataan arsip \\
yang tidak tertata dengan baik sehingga membutuhkan waktu yang lumayan lama \\
dalam pencarian arsip. \\
2. Tidak ada backup data arsip perkara ketika terjadi kerusakan, dalam hal ini teridiri \\
dari berita acara sidang, persyaratan berkas perkara, data para pihak yang \\
berperkara. \\
3. Jumlah Arsip yang semakin bertambah mengakibatkan tempat ruang \\
penyimpanan yang tersedia tidak dapat menampung arsip lagi. \\
4. Pencatatan data arsip masih dilakukan dengan manual yaitu dengan mencatat \\
kedalam buku kendali penerimaan arsip. \\
5. Kesulitan dalam pembuatan laporan penerimaan arsip sehingga dalam penyerahan \\
laporan kepada pimpinan selalu mengalami keterlambatan. \\
\hline Mempengaruhi \\
Efektivitas pelayanan masyarakat yang prima serta dalam jalannya proses pembuatan \\
laporan pengarsipan. \\
1. Kecepatan dan ketepatan dalam memperoleh informasi yang terkandung dalam \\
arsip perkara menurun. \\
2. Arsip perkara menjadi rawan rusak dikarenakan suatu bencana yang tak terduga. \\
3. Menghambat jalan-nya pekerjaan petugas arsip \\
4. Menurunkan produktivitas instansi \\
5. Berpengaruh pada pengambilan keputusan pimpinan \\
Dengan mengikuti perkembangan teknologi saat ini dan bertransformasi ke arah \\
digital dengan menggunakan sebuah sistem yang dapat membantu dalam \\
pengelolaan arsip perkara, pencarian arsip perkara, pembuatan laporan arsip perkara \\
dan mampu membackup data arsip perkara.
\end{tabular}

Kemudian dari hasil proses identifikasi terhadap proses bisnis yang berjalan saat ini dan analisis permasalahan maka dilakukan perbaikan dan di modelkan kembali dalam bentuk proses bisnis usulan. Dalam penelitian ini proses bisnis usulan didefinisikan dengan mengubah berbagai aktivitas manual yang menyebabkan proses pengelolaan arsip perkara menjadi tidak optimal.

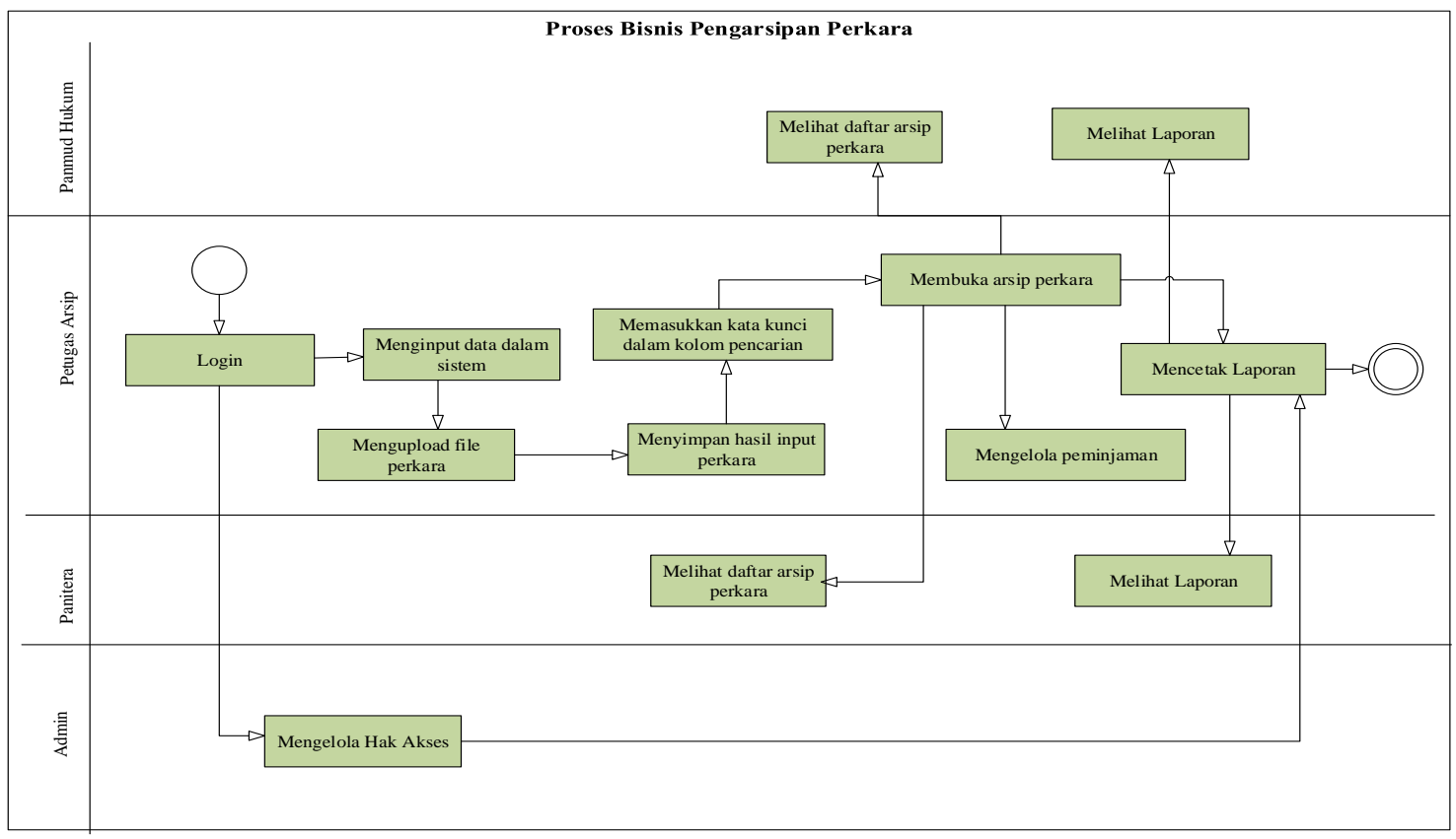

Gambar 2. Proses Bisnis Usulan 


\subsection{Analisis Persyaratan}

Analisis persyaratan merupakan tahapan yang dilakukan untuk mengidentifikasi kebutuhan hingga mengubah kebutuhan tersebut menjadi berbagai aktivitas yang mampu menyelesaikan kebutuhan tersebut. Analisis persyaratan terdiri dari identifikasi pemangku kepentingan dan pengguna, indentifikasi pernyataan kedudukan produk, dan identifikasi fitur. Dari indetifikasi fitur dapat di identifikasikan persyaratan fungsional dan persyaratan non fungsional

\subsubsection{Identifikasi Pemangku Kepentingan dan Pengguna}

Identifikasi Pemangku kepentingan mencakup semua pihak yang terkait dalam pengelolaan terhadap sumberdaya yang terdiri dari pengguna, pemilik sistem, dan pengembang, berikut penjelasan terdapat didalam tabel 2.

Tabel 2. Tipe Pemangku Kepentingan

\begin{tabular}{|c|c|c|c|}
\hline No & $\begin{array}{l}\text { Tipe Pemangku } \\
\text { Kepentingan }\end{array}$ & Pemangku Kepentingan & $\begin{array}{l}\text { Pemangku kepentingan yang } \\
\text { relevan }\end{array}$ \\
\hline 1 & Pengguna & $\begin{array}{l}\text { Orang yang langsung menggunakan } \\
\text { atau mengoperasikan sistem }\end{array}$ & Staf Arsip \\
\hline 2 & Pemilik Sistem & $\begin{array}{l}\text { Instansi yang mengelola pengarsipan } \\
\text { perkara yang akan menjadi pemilik dari } \\
\text { sistem }\end{array}$ & $\begin{array}{l}\text { Pengadilan Agama Jambi } \\
\text { Kelas IA }\end{array}$ \\
\hline 3 & $\begin{array}{l}\text { Pengembang/ } \\
\text { developer }\end{array}$ & $\begin{array}{l}\text { Sekelompok orang yang bertanggung } \\
\text { jawab dalam Pengembangan perangkat } \\
\text { lunak }\end{array}$ & $\begin{array}{ll}\text { Analisis } & \text { system } \\
\text { Programmer } & \end{array}$ \\
\hline
\end{tabular}

\subsubsection{Identifikasi Persyaratan Kedudukan Produk}

Setelah mengindentfikasikan pemangku kepentingan selanjutnya mengidentifikasi persyaratan kedudukan produk yang berisikan tentang apa saja yang bisa dilakukan oleh sistem yang akan dirancang berikut penjelasanya pada tabel 3 .

Tabel 3. Persyaratan Kedudukan Produk

\begin{tabular}{ll}
\hline Untuk & Staf Arsip \\
\hline $\begin{array}{l}\text { Yang } \\
\text { melakukan }\end{array}$ & Pengelolan arsip perkara di pengadilan agama jambi \\
\hline Sistem & $\begin{array}{l}\text { Sistem informasi pengelolaan arsip perkara berbasis web merupakan sistem yang } \\
\text { membantu didalam pengelolaan arsip perkara }\end{array}$ \\
\hline Yang mampu & $\begin{array}{l}\text { Menyediakan fitur-fitur seperti pencarian arsip, mengupload atau mengunggah } \\
\text { file arsip, mencetak laporan arsip. }\end{array}$ \\
\hline Tidak seperti & $\begin{array}{l}\text { Kondisi saat ini dimana pengelolaan arsip perkara dilakukan secara manual, } \\
\text { sulitnya dalam penemuan kembali arsip, dan tidak adanya backup data arsip } \\
\text { perkara. }\end{array}$ \\
\hline Produk kami & $\begin{array}{l}\text { Memudahkan dalam pengelolaan arsip perkara, dalam pencarian arsip perkara, } \\
\text { dan dalam pembuatan laporan penerimaan arsip perkara. }\end{array}$ \\
\hline
\end{tabular}

\subsubsection{Identifikasi Fitur}

Setelah mengindentifikasi persyaratan kedudukan priduk selanjutnya mengindentifikasi fitur yang terdapat pada sistem yang ditawarkan, adapun tujuan indetifikasi fitur ini digunakan untuk menyusun spesifikasi kebutuhan perangkat lunak yang akan dirancang, pada tabel 4 berikut ini merupakan penjelasan masing-masing kode fitur beserta deskripisi masing-masing fitur yang digunakan. 
Tabel 4. Identifikasi Fitur

\begin{tabular}{|c|c|c|c|}
\hline No & $\begin{array}{l}\text { Kode } \\
\text { Fitur }\end{array}$ & Nama Fitur & Deskripsi \\
\hline 1. & F-01 & Login & $\begin{array}{l}\text { Sistem dapat digunakan untuk melakukan } \\
\text { autentifikasi pada sistem }\end{array}$ \\
\hline 2. & $\mathrm{~F}-02$ & $\begin{array}{l}\text { Memasukkan data Arsip } \\
\text { Perkara }\end{array}$ & $\begin{array}{l}\text { Sistem dapat digunakan untuk memasukkan data } \\
\text { arsip perkara }\end{array}$ \\
\hline 3. & $\mathrm{~F}-03$ & Menyimpan data Arsip & $\begin{array}{l}\text { Sistem dapat digunakan untuk menyimpan data } \\
\text { arsip perkara }\end{array}$ \\
\hline 4. & $\mathrm{~F}-04$ & Menampilkan data Arsip & $\begin{array}{l}\text { Sistem dapat digunakan untuk menampilkan data } \\
\text { arsip perkara }\end{array}$ \\
\hline 5. & F-05 & $\begin{array}{l}\text { Mencari data Arsip } \\
\text { Perkara }\end{array}$ & $\begin{array}{l}\text { Sistem dapat digunakan untuk mencari data arsip } \\
\text { perkara yang telah tersimpan dalam sistem }\end{array}$ \\
\hline 6. & F-06 & $\begin{array}{l}\text { Mengubah data Arsip } \\
\text { perkara }\end{array}$ & $\begin{array}{l}\text { Sistem dapat digunakan untuk mengubah data arsip } \\
\text { perkara yang telah tersimpan dalam sistem }\end{array}$ \\
\hline 7. & $\mathrm{~F}-07$ & $\begin{array}{l}\text { Menghapus data Arisp } \\
\text { Perkara }\end{array}$ & $\begin{array}{l}\text { Sistem dapat digunakan untuk menghapus data } \\
\text { arsip perkara yang telah tersimpan dalam sistem }\end{array}$ \\
\hline 8. & F-08 & $\begin{array}{l}\text { Mengupload data Arsip } \\
\text { Perkara }\end{array}$ & $\begin{array}{l}\text { Sistem dapat digunakan untuk mengupload file data } \\
\text { arsip perkara tentunya yang telah selesai proses } \\
\text { scan. }\end{array}$ \\
\hline 9. & F-09 & Download & $\begin{array}{l}\text { Sistem dapat digunakan untuk mendownload file } \\
\text { arsip }\end{array}$ \\
\hline 10. & F-10 & $\begin{array}{l}\text { Memasukakan daftar } \\
\text { Peminjaman Arsip }\end{array}$ & $\begin{array}{l}\text { Sistem dapat digunakan untuk menambah daftar } \\
\text { peminjaman arsip }\end{array}$ \\
\hline 11. & F-11 & Riwayat Peminjaman & $\begin{array}{l}\text { Sistem dapat digunakan untuk menampilkan } \\
\text { riwayat peminjaman arsip perkara. }\end{array}$ \\
\hline 12. & F-12 & $\begin{array}{l}\text { Mengubah data } \\
\text { peminjaman }\end{array}$ & $\begin{array}{l}\text { Sistem dapat digunakan untuk mengubah data } \\
\text { peminjaman arsip perkara. }\end{array}$ \\
\hline 13. & F-13 & Mencetak Laporan & $\begin{array}{l}\text { Sistem dapat digunakan untuk mencetak Laporan } \\
\text { data arsip perkara yang telah tersimpan dalam } \\
\text { sistem }\end{array}$ \\
\hline 14 & F-14 & Logout & Sistem dapat digunakan untuk keluar dari sistem \\
\hline
\end{tabular}

\subsubsection{Persyaratan Fungsional}

Setelah mengindentifikasi fitur selanjutnya mengidentifikasi Persyaratan fungsional tujuan dari identifikasi persyaratan fungsional ini adalah menentukan apa yang akan dilakukan sistem atau aplikasi khususnya dalam konteks interaksi eksternal. Pada tabel 5 berikut ini merupakan beberapa persyaratan fungsional yang ada di dalam sistem yang akan dirancang.

Tabel 5. Persyaratan Fungsional

\begin{tabular}{llll}
\hline No & Kode Fitur & $\begin{array}{l}\text { Kode persyaratan } \\
\text { fungsional }\end{array}$ & \multicolumn{1}{c}{ Deskripsi } \\
\hline 1. & F-01 & $\begin{array}{l}\text { SKP-FU-P01 } \\
\text { SKP-FU-P01-1 }\end{array}$ & $\begin{array}{l}\text { Sistem dapat digunakan untuk login kedalam sistem dan } \\
\text { mengelola hak akses. }\end{array}$ \\
\hline 2. & F-02 & SKP-FU-P02 & Sistem dapat digunakan untuk memasukkan data arsip perkara \\
\hline 3. & F-03 & SKP-FU-P03 & Sistem dapat digunakan untuk menyimpan data arsip perkara \\
\hline 4. & F-04 & SKP-FU-P04 & $\begin{array}{l}\text { Sistem dapat digunakan untuk menampilkan data arsip } \\
\text { perkara }\end{array}$ \\
\hline 5. & F-05 & SKP-FU-P05 & $\begin{array}{l}\text { Sistem dapat digunakan untuk mencari data arsip perkara } \\
\text { yang telah tersimpan dalam sistem }\end{array}$ \\
\hline 6. & F-06 & SKP-FU-P06 & $\begin{array}{l}\text { Sistem dapat digunakan untuk mengubah data arsip perkara } \\
\text { yang telah tersimpan dalam sistem }\end{array}$ \\
\hline 7. & F-07 & SKP-FU-P07 & $\begin{array}{l}\text { Sistem dapat digunakan untuk menghapus data arsip perkara } \\
\text { yang telah tersimpan dalam sistem }\end{array}$ \\
\hline
\end{tabular}




\begin{tabular}{llll}
\hline 8. & F-08 & SKP-FU-P08 & $\begin{array}{l}\text { Sistem dapat digunakan untuk mengupload file data arsip } \\
\text { perkara tentunya yang telah selesai proses scan. }\end{array}$ \\
\hline 9. & F-09 & SKP-FU-P09 & Sistem dapat digunakan untuk mendownload file arsip \\
\hline 10. & F-10 & SKP-FU-P10 & $\begin{array}{l}\text { Sistem dapat digunakan untuk menambah daftar peminjaman } \\
\text { arsip }\end{array}$ \\
\hline 11. & F-11 & SKP-FU-P11 & $\begin{array}{l}\text { Sistem dapat digunakan untuk menampilkan riwayat } \\
\text { peminjaman arsip perkara. }\end{array}$ \\
\hline 12. & F-12 & SKP-FU-P12 & $\begin{array}{l}\text { Sistem dapat digunakan untuk mengubah data peminjaman } \\
\text { arsip perkara. }\end{array}$ \\
\hline 13. & F-13 & SKP-FU-P13 & $\begin{array}{l}\text { Sistem dapat digunakan untuk mencetak Laporan data arsip } \\
\text { perkara }\end{array}$ \\
\hline 14 & F-14 & SKP-FU-P14 & Sistem dapat digunakan untuk keluar dari sistem \\
\hline
\end{tabular}

\subsubsection{Persyaratan Non Fungsional}

Selanjutnya identifikasi persyaratan non fungsional dengan tujuan untuk mengetahui persyaratan apa pun yang tidak menggambarkan perilaku input atau output sistem. Pada tabel 6 berikut ini persyaratan Non Fungsional yang terdapat pada sistem yang akan dirancang.

Tabel 6. Persyaratan Non Fungsional

\begin{tabular}{clll}
\hline \multicolumn{1}{c}{ Kode } & \multicolumn{1}{c}{ Nama } & \multicolumn{1}{c}{ Deskripsi } \\
\hline 1. & SKP-NFU-P1 & Performance & Sistem dapat memberikan informasi secara real time \\
\hline 2. & SKP-NFU-P2 & Usability & $\begin{array}{l}\text { Sistem memiliki tampilan antarmuka yang mudah } \\
\text { dipahami oleh pengguna }\end{array}$ \\
\hline 3. & SKP-NFU-P3 & Accessibility & $\begin{array}{l}\text { Sistem dapat diakses oleh pengguna melalui jaringan } \\
\text { internet }\end{array}$ \\
\hline
\end{tabular}

\subsection{Use Case Diagram}

Di dalam memodelkan suatu rancangan sistem dibutuhkan satu model perancagan yaitu use case dimana use case menggambarkan alur yang akan dibuat dan mampu menjelaskan tentang actor dan dapat melakukan aktivitas apa saja yang terdapat didalam sistem [9]. Berikut merupakan use case diagram pengelolaan arsip perkara pada gambar 3 dibawah ini.

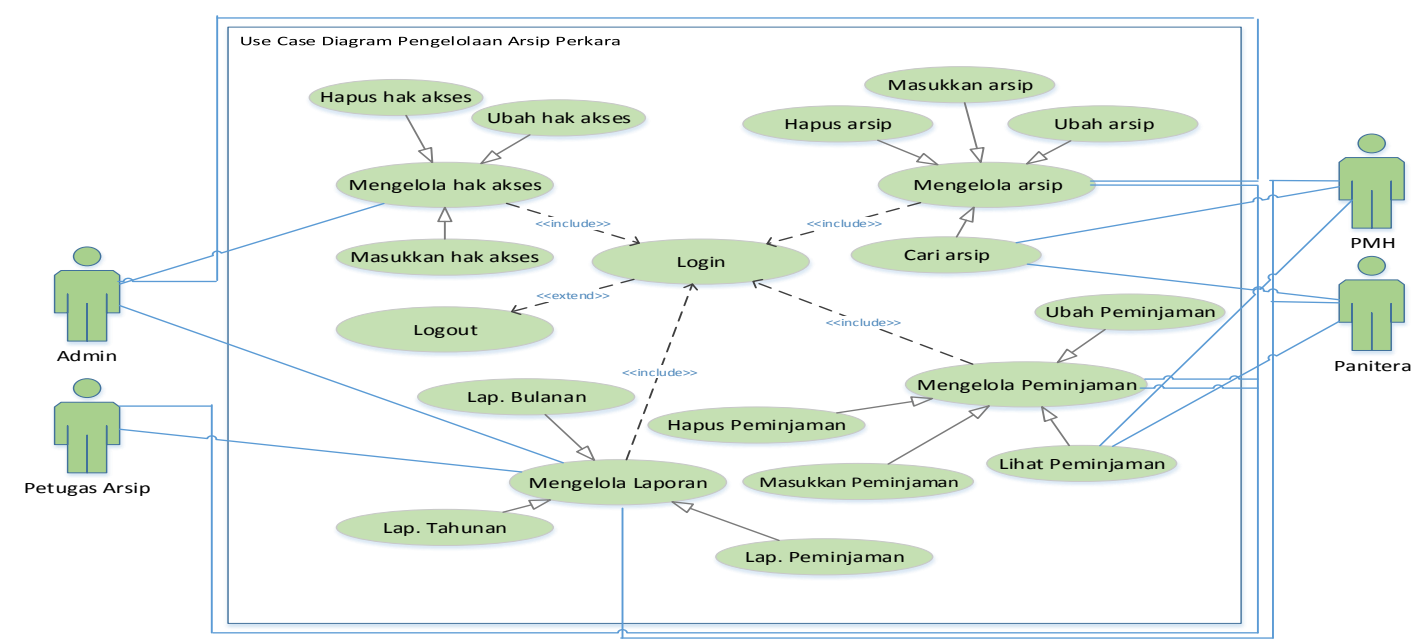

Gambar 3. Use Case Diagram Pengelolaan Arsip Perkara

\subsection{Class Diagram}

Class Diagram menghubungkan antara kelas dan penjelasan pada setiap kelas, class diagram juga memperlihatkan aturan serta tanggung jawab setiap entitas, selain itu class diagram juga menunjukkan atribut-atribut serta operasi-operasi suatu kelas [10]. Pada class diagram yang terdapat pada gambar 4 
berikut ini memiliki 6 tabel dengan masing-masing relasi yang saling terhubung antara satu tabel dengan tabel lainnya. Berikut ini merupakan class diagram pengelolaan arsip perkara.

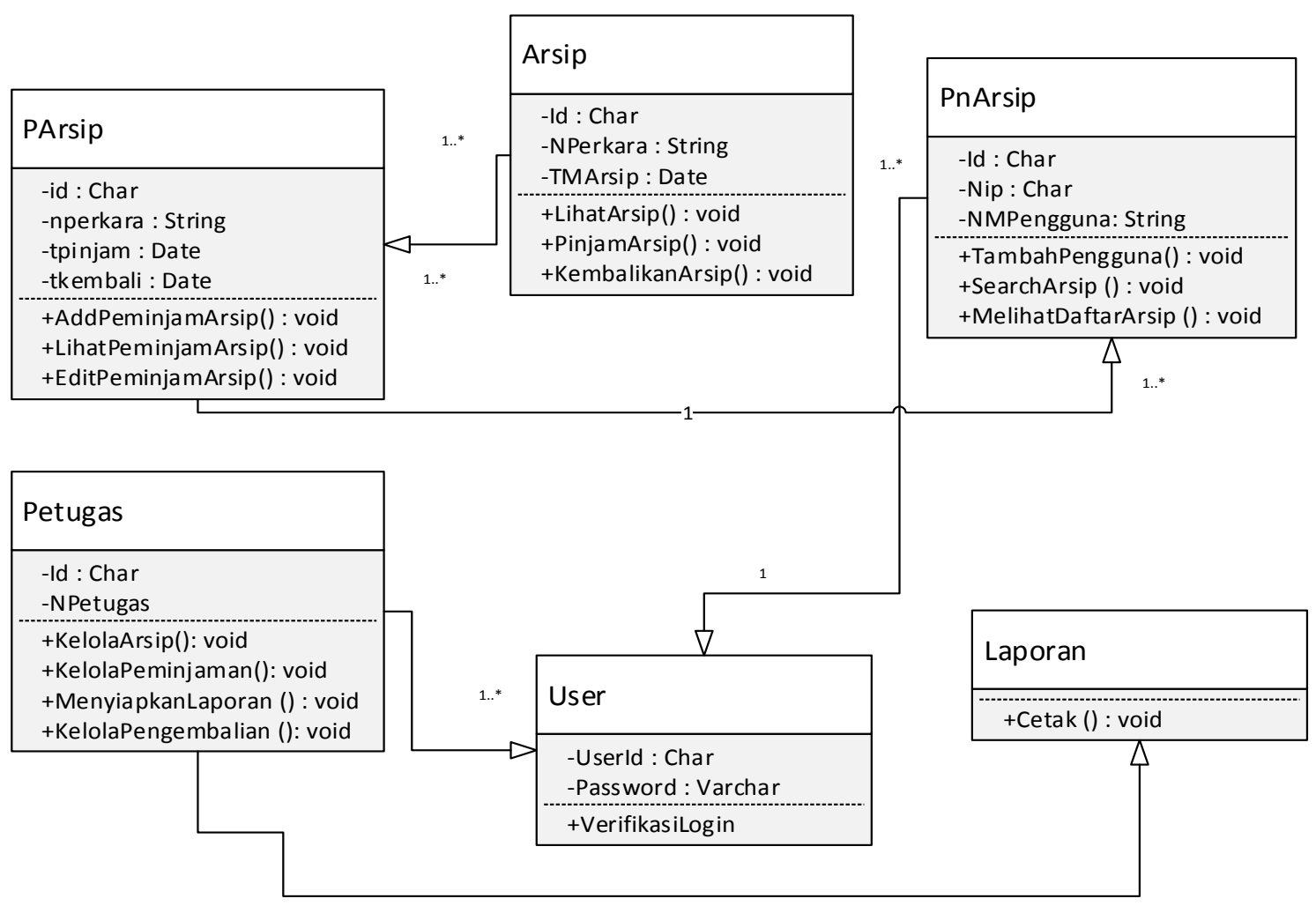

Gambar 4. Class Diagram Pengelolaan Arsip Perkara

\subsection{Hasil Implementasi}

Tujuan dari impelementasi adalah menerapkan perancangan pada kondisi yang sebenarnya.

1. Menu Login User

Tampilan menu login user ini digunakan oleh Pengguna sistem yang telah terdaftar untuk dapat mengakses sistem.

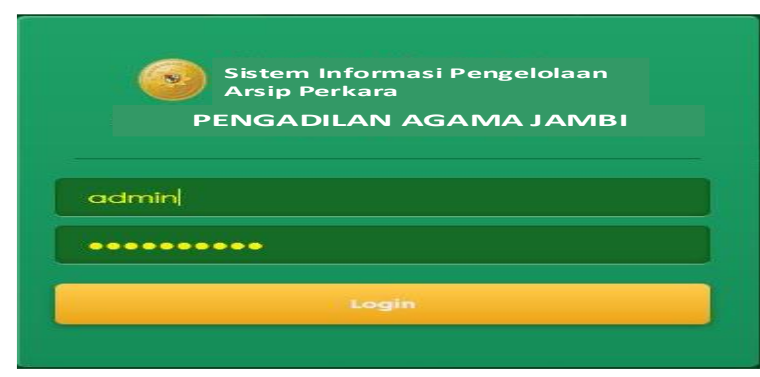

Gambar 5. Form Login User

2. Tampilan Tambah Data Arsip

Tampilan tambah data arsip ini merupakan form yang digunakan untuk melakukan input data arsip yang dapat digunakan oleh user petugas arsip. 


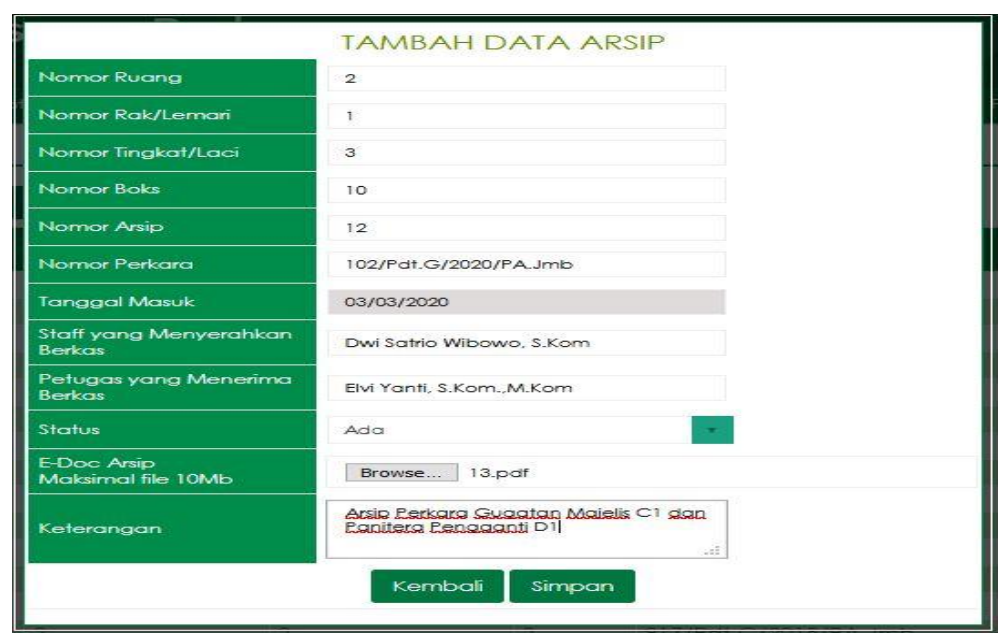

Gambar 6. Form Tambah Data Arsip

Form Tambah data arsip ini wajib diisi oleh petugas arsip ketika ingin melakukan penginputan arsip setiap record yang diinputkan harus sesuai dengan field yang ada, seperti field nomor ruang yang harus di isi dengan angka karena menunjukkan nomor ruangan arsip yang digunakan dalam menyimpan arsip, begitupun dengan field nomor rak/lemari digunakan untuk menyimpan nomor rak dengan tujuan untuk mengetahui letak rak arsip, field nomor tingkat/laci digunakan untuk menyimpan nomor laci dengan tujuan untuk mengetahui laci nomor berapa arsip tersebut disimpan, field nomor boks digunakan untuk menyimpan nomor boks dengan tujuan untuk mengetahui boks nomor berapa yang digunakan sebagai boks arsip, field nomor arsip digunakan untuk menyimpan nomor arsip dengan tujuan untuk mengetahui urutan nomor arsip, field nomor perkara digunakan untuk menyimpan nomor perkara yang di simpan di dalam arsip, field tanggal masuk digunakan untuk menyimpan tanggal minutasi berkas arsip, field staff yang menyerahkan menyimpan record staff yang menyerahkan arsip, petugas yang menerima berkas, field status digunakan untuk menyimpan keadaan berkas, field e-doc arsip digunakan untuk menyimpan file berkas yang telah di scan, dan field keterangan digunakan untuk menyimpan catatan berkas perkara tersebut.

3. Tampilan Cari Data Arsip

Tampilan cari data arsip merupakan form yang digunakan untuk mencari data arsip. Form cari data arsip ini memberikan informasi terkait dengan arsip yang dibutuhkan, penggunaannya sangat simple sekali tinggal menginputkan nomor perkara yang telah diinputkan pada form tambah data arsip, dengan catatan nomor yang di inputkan sesuai dengan yang terdaftar di pengadilan agama jambi.

\begin{tabular}{|c|c|c|c|c|c|c|c|c|c|}
\hline 864 & & Search & Tambch Asip & & & & \multicolumn{3}{|c|}{ Fer 1 Nex } \\
\hline No & Nomor Arip & Nomor Ruong & Nomor Rakl:Lmani & Nomor Tingkat/loci & \begin{tabular}{|l} 
Noloror \\
Booss
\end{tabular} & Nomor Perkara & Tanggal Masuk & SYatus & Link \\
\hline 1 & & 2 & 2 & 2 & 2 & 850/Pd:G/2018/PA.Jmb & 18Des. 2018 & Ada & [detii] \\
\hline
\end{tabular}

Gambar 7. Form Cari Arsip

4. Tampilan Melihat Infromasi Detail Arsip

Tampilan melihat informasi detail arsip ini merupakan form yang digunakan untuk melihat keadaan arsip secara keseluruhan, dari mengetahui nomor arsip yang digunakan sampai pengguna dapat mendownload edoc atau dokumen arsip. Selain untuk mengetahui detail arsip pengguna juga dapat melihat data peminjaman arsip yang dijelaskan pada gambar 9 berikut ini. 


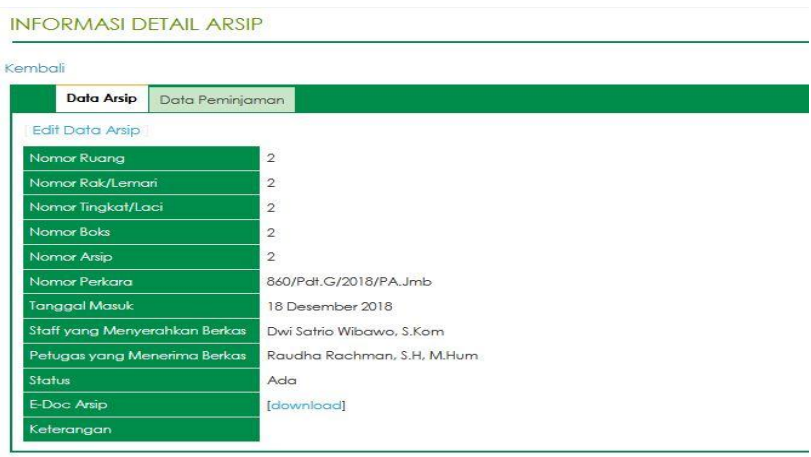

Gambar 8. Form Informasi Detail Arsip

5. Tampilan Tambah Data Pinjaman Arsip

Tampilan Tambah Data Pinjaman Arsip merupakan form yang digunakan untuk menambah data peminjaman arsip, didalam form pinjaman arsip ini dapat diketahui siapa saja dan untuk apa arsip itu dipinjam.

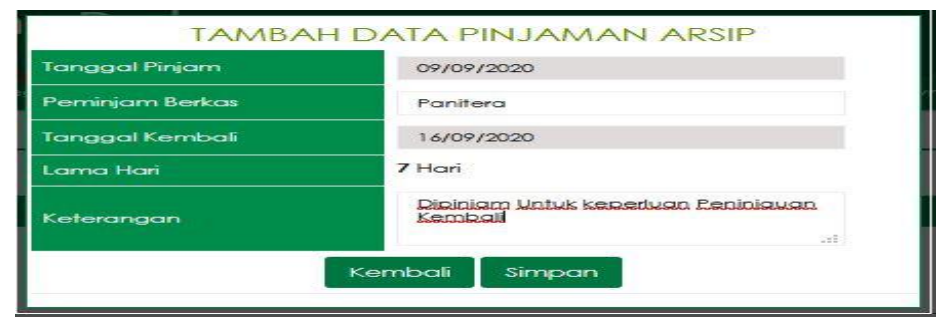

Gambar 9. Form Peminjaman Arsip

6. Laporan Hasil Peminjaman Arsip dan Laporan Keadaan Arsip

Laporan hasil peminjaman arsip ini merupakan rekapan peminjaman arsip setiap bulan yang mencakup tanggal peminjaman, user yang meminjam, tanggal pengembalian, nomor perkara dan keterangan untuk apa arsip tersebut dipinjam. Laporan peminjaman arsip ini dapat dilihat pada gambar 10 berikut.

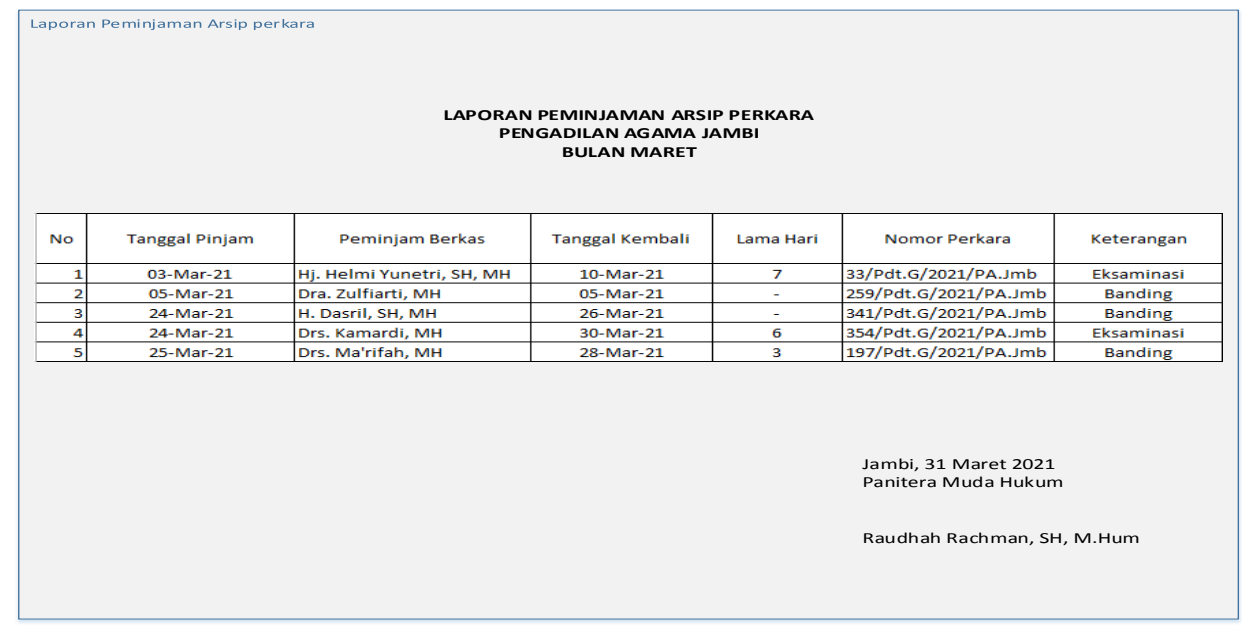

Gambar 10. Laporan Peminjaman Arsip

Laporan hasil arsip perkara merupakan rekapan penerimaan arsip setiap bulan yang mencakup keadaan arsip dari nomor arsip, nomor ruang, nomor rak, nomor perkara, tanggal masuk hingga status keadaan arsip. Laporan arsip ini dapat dilihat pada gambar 11 berikut. 


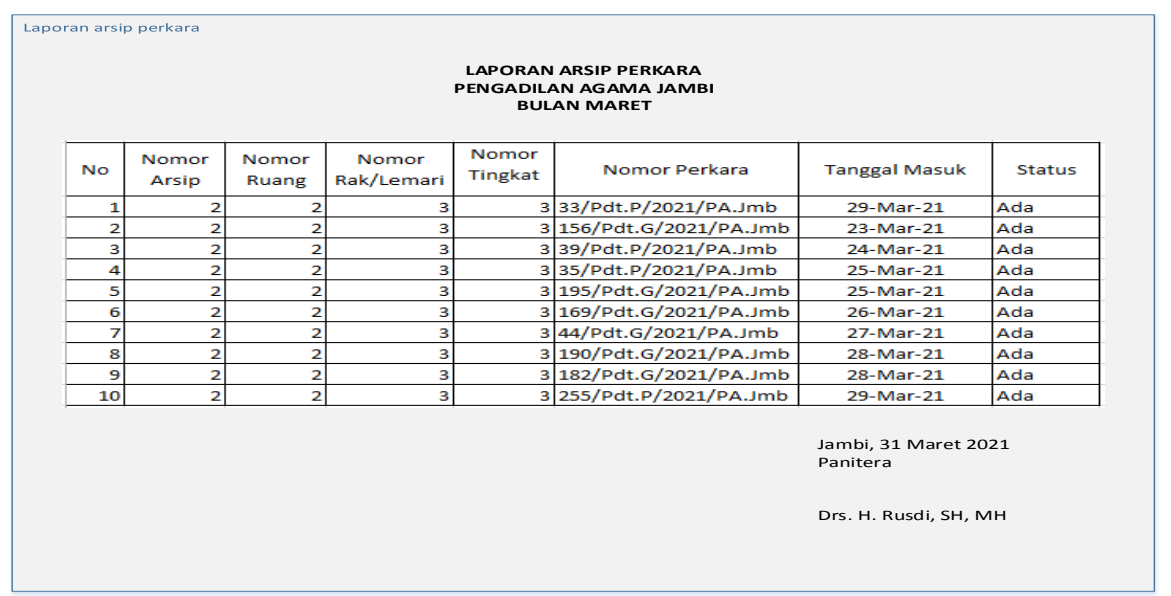

Gambar 11. Laporan Peminjaman Arsip

\subsection{Evaluasi}

Berikut hasil evaluasi yang telah dilakukan :

1. Traceability Matrix

Dengan dilakukan Traceability Matrix diharapkan kita dapat mengetahui apakah perancangan yang telah dibuat telah mengakomodasi semua analisis yang telah didefinisikan sebelumnya pada tabel berikut ini merupakah hasil Traceability Matrik yang terdiri dari pemodelan proses bisnis hingga antarmuka pengguna.

Tabel 7. Traceability Matrix

\begin{tabular}{|c|c|c|c|c|c|}
\hline $\begin{array}{l}\text { Kode } \\
\text { Proses } \\
\text { Bisnis }\end{array}$ & $\begin{array}{l}\text { Kode } \\
\text { Persyaratan } \\
\text { Fungsional }\end{array}$ & $\begin{array}{l}\text { Kode Use } \\
\text { Case }\end{array}$ & $\begin{array}{l}\text { Nama Use } \\
\text { Case }\end{array}$ & $\begin{array}{l}\text { Kode } \\
\text { Diagram } \\
\text { Sequence }\end{array}$ & $\begin{array}{l}\text { Kode } \\
\text { Antarmuka } \\
\text { Pengguna }\end{array}$ \\
\hline PB-01 & $\begin{array}{l}\text { SKP-FU-P01 } \\
\text { SKP-FU-P01-1 }\end{array}$ & $\begin{array}{l}\text { UC-01 } \\
\text { UC-02 }\end{array}$ & $\begin{array}{l}\text { Login, } \\
\text { Mengelola Hak } \\
\text { Akses }\end{array}$ & $\begin{array}{l}\text { SD-01, SD-03, } \\
\text { SD-04 }\end{array}$ & $\begin{array}{l}\text { AP-01, AP-03, } \\
\text { AP-04, AP-05 }\end{array}$ \\
\hline PB-02 & SKP-FU-P02 & UC-03 & $\begin{array}{l}\text { Mengelola } \\
\text { Arsip }\end{array}$ & SD-06 & AP-06 \\
\hline PB-03 & $\begin{array}{l}\text { SKP-FU-P08, } \\
\text { SKP-FU-P09 }\end{array}$ & UC-03 & $\begin{array}{l}\text { Mengelola } \\
\text { Arsip }\end{array}$ & SD-06 & AP-06 \\
\hline PB-04 & $\begin{array}{l}\text { SKP-FU-P03, } \\
\text { SKP-FU-P07, } \\
\text { SKP-FU-P06, }\end{array}$ & UC-03 & $\begin{array}{l}\text { Mengelola } \\
\text { Arsip }\end{array}$ & $\begin{array}{l}\text { SD-06, SD-08, } \\
\text { SD-07 }\end{array}$ & $\begin{array}{l}\text { AP-06, AP-08, } \\
\text { AP-07 }\end{array}$ \\
\hline PB-05 & $\begin{array}{l}\text { SKP-FU-P04, } \\
\text { SKP-FU-P05 }\end{array}$ & UC-03 & $\begin{array}{l}\text { Mengelola } \\
\text { Arsip }\end{array}$ & SD-09 & AP-09 \\
\hline PB-06 & SKP-FU-P04, & UC-03 & $\begin{array}{l}\text { Mengelola } \\
\text { Arsip }\end{array}$ & SD-09 & AP-09 \\
\hline PB-07 & $\begin{array}{l}\text { SKP-FU-P10, } \\
\text { SKP-FU-P11, } \\
\text { SKP-FU-P12 }\end{array}$ & UC-04 & $\begin{array}{l}\text { Mengelola } \\
\text { Peminjaman }\end{array}$ & $\begin{array}{l}\text { SD-10, SD-11, } \\
\text { SD-12, SD-14 }\end{array}$ & $\begin{array}{l}\text { AP-10, AP-11, } \\
\text { AP-12, AP-14 }\end{array}$ \\
\hline PB-08 & SKP-FU-P13 & UC-05 & $\begin{array}{l}\text { Mengelola } \\
\text { Laporan }\end{array}$ & SD-15 & AP-15 \\
\hline PB-09 & SKP-FU-P14 & UC-06 & Logout & SD-16 & AP-16 \\
\hline
\end{tabular}

2. Hasil Analisa Traceability

Hasil analisa Traceability dilakukan oleh perancang dengan tujuan untuk mengetahui apakah pembuatan Traceability Matrix telah memenuhi semua kebutuhan pengguna. Pada tabel 8 berikut ini menjelaskan tentang hasil analisa menggunakan traceability matrix. 
Tabel 8. Hasil Analisa Traceability

\begin{tabular}{|c|c|c|c|}
\hline No & Pertanyaan & Tidak & Keterangan \\
\hline 1 & $\begin{array}{ll}\text { Apakah persyaratan yang } \\
\text { digunakan telah terdefinisikan } \\
\text { dengan baik dan unik? }\end{array}$ & Ya & $\begin{array}{l}\text { Semua persyaratan telah } \\
\text { didefinisikan degan baik dan } \\
\text { memiliki kode yang unik dengan } \\
\text { mengkombinasikan angka dan } \\
\text { huruf }\end{array}$ \\
\hline 2 & $\begin{array}{l}\text { Apakan persyaratan fungsional } \\
\text { sistem yang digunakan dapat } \\
\text { ditelusuri? seperti menggunakan } \\
\text { use case? }\end{array}$ & Ya & $\begin{array}{l}\text { Semua persyaratan fungsional } \\
\text { dari sistem dapat ditelusuri } \\
\text { dengan dibuktikan menggunakan } \\
\text { tabel traceability matrix }\end{array}$ \\
\hline 3 & $\begin{array}{l}\text { Apakah rancangan antarmuka dapat } \\
\text { ditelusuri atau dilacak berdasarkan } \\
\text { persyaratan yang digunakan? }\end{array}$ & ya & $\begin{array}{llr}\text { Setiap } & \text { bagian } & \text { rancangan } \\
\text { antarmuka } & \text { dapat } & \text { ditelusuri } \\
\text { kembali } & \text { sesuai persyaratan } \\
\text { dengan dibuktikan menggunakan } & \text { mel } \\
\text { tabel traceability matrix }\end{array}$ \\
\hline
\end{tabular}

3. Pengujian Prototype

Pengujian prototype ini dilakukan dengan meminta pengguna sistem untuk menjalankan scenario yang telah dirancang. Dari pengujian prototype dengan 7 scenario, 7 Activity dan 16 Squence Diagram terhadap satu Pengguna diperoleh hasil bahwa semua alur telah memenuhi keinginan yang diharapkan.

\section{Kesimpulan}

Hasil dari analisis persyaratan pada peneltian ini terdiri dari 8 proses bisnis, 14 fitur, 14 persyaratan fungsional, 3 persyaratan non fungsional, dan 4 aktor terdiri dari 6 use case yaitu login, mengelola hak akses, mengelola arsip, mengelola peminjaman, mengelola laporan, dan logout. Hasil evaluasi dari analisis dan perancangan sistem diperoleh hasil evaluasi menggunakan metode traceability matrix dapat diambil kesimpulan bahwa semua kebutuhan telah teridentifikasi. Sedangkan evaluasi menggunakan pengujian prototype diperoleh hasil bahwa semua alur dari scenario telah sesuai dengan yang diharapkan pengguna.

\section{Daftar Pustaka}

[1] M. Fathurrahman, "Pentingnya Arsip Sebagai Sumber Informasi," JIPI (Jurnal Ilmu Perpust. dan Informasi), vol. 3, no. 2, pp. 215-225, 2018, [Online]. Available: http://jurnal.uinsu.ac.id/index.php/jipi/article/view/3237/1917.

[2] Azmi, “ANRI Jurnal Kearsipan,” ANRI J. Kearsipan, vol. 11, pp. 1-135, 2016.

[3] A. T. Helmi, I. Aknuranda, and M. C. Saputra, "Analisis Dan Pemodelan Proses Bisnis Menggunakan Business Process Improvement (BPI) Pada Lembaga Bimbingan Belajar (Studi Kasus: Lembaga Bimbingan Belajar Prisma)," J. Pengemb. Teknol. Inf. dan Ilmu Komput. Univ. Brawijaya, vol. 2, no. 10, pp. 4184-4191, 2018.

[4] M. D. Irawan and S. A. Simargolang, "Implementasi E-Arsip Pada Program Studi Teknik Informatika," J. Teknol. Inf., vol. 2, no. 1, p. 67, 2018, doi: 10.36294/jurti.v2i1.411.

[5] R. Turaina, E. Elizamiharti, and H. E. Rahma, "Sistem Informasi Pengarsipan Berkas Perkara Pidana dan Perdata pada Pengadilan Negeri Klas IA Padang," Indones. J. Comput. Sci., vol. 6, no. 1, pp. 12-30, 2018, doi: 10.33022/ijcs.v6i1.11.

[6] R. P. Bendriyanti and L. N. Zulita, "Implementasi E-Arsip Pada Kanwil Kementerian Agama Provinsi Bengkulu," J. Media Infotama, vol. 8, no. 1, pp. 158-177, 2012, [Online]. Available: http://jurnal.unived.ac.id/index.php/jmi/article/view/77.

[7] A. Triwahyuni, "Aplikasi E- Arsip Pada Stmik Palcomtech Palembang," Semin. Nas., vol. 2011, no. semnasIF, pp. 157-163, 2011. 
[8] F. Purwaningtias, "E-Commerce Penjualan Berbasis Metode Ooad," J. Cendikia, vol. XV, no. April, pp. 1-5, 2018, [Online]. Available: https://jurnal.dcc.ac.id/index.php/JC/article/view/52.

[9] F.- Sonata, "Pemanfaatan UML (Unified Modeling Language) Dalam Perancangan Sistem Informasi E-Commerce Jenis Customer-To-Customer," J. Komunika J. Komunikasi, Media dan Inform., vol. 8, no. 1, p. 22, 2019, doi: 10.31504/komunika.v8i1.1832.

[10] A. Hendini, "Pemodelan Uml Sistem Informasi Monitoring Penjualan Dan Stok Barang," $J$. Khatulistiwa Inform., vol. 2, no. 9, pp. 107-116, 2016, doi: 10.1017/CBO9781107415324.004. 